DOI: https://doi.org/10.3126/tgb.v6i0.26163

\title{
A Review of Studies on Climate Change in Nepal
}

\author{
Payaswini Ghimire1
}

\begin{abstract}
Climate change is now a global issue and its impact on different sectors like water sources, biodiversity, health, livestock, and livelihood are already seen. Climate change is accelerating due to the emission of greenhouse gases produced by anthropogenic activities. Though Nepal's contribution to greenhouse gases is negligible compared to developed countries, its risk to climate change is very high. Thus, it extremely important to understand the current scenario of climate change of Nepal. Hence, this article reviews and compares the published articles which studies the pattern and trend of climate change of the time period of at least 30 years. Most of the article shows increasing trend of temperature. According to the recent study, maximum temperature was found to be increasing by $0.05^{\circ} \mathrm{C} /$ year and minimum temperature was found to increase by $0.03^{\circ} \mathrm{C} /$ year. Though, the trend of precipitation in Nepal is not clear like temperature most of the studies have concluded increasing in monsoon precipitation in coming years.
\end{abstract}

Key words: climate change, climate trend, climate projection, people's perception

\section{Introduction}

The change in climate over a certain period due to natural processes or human interaction with environment is called climate change (IPCC, 2014). Climate change is one of the major issues at both national and international levels (Khadka \& Pathak, 2016). Various studies have concluded that the global mean temperature and global mean precipitation has been increasing (IPCC, 2012; Gu \& Adler, 2015). Climate change due to human activities have caused about $1^{\circ} \mathrm{C}$ of global warming above pre-industrial levels with range of $0.8^{\circ}$ to $1.2^{\circ} \mathrm{C}$ (IPCC, 2018). IPCC (2018) have estimated that if the greenhouse gas emission continues at the same rate the global warming will likely reach $1.5^{\circ} \mathrm{C}$ between 2030 and 2052. Though the major contributors of greenhouse gases are developed countries the consequences of climate change are most felt by developing countries i.e. those who are most vulnerable (Maharjan, Sigdel, Sthapit \& Regmi, 2011; Devkota, 2014).

\footnotetext{
${ }^{1}$ Central Department of Geography, Tribhuvan University. Corresponding e-mail: payaswini@gmail.com
} 
Nepal is a country which has complex climate that varies greatly due to its topography (McSweeney \& Lizcano, 2008). Nepal has lowland regions with warm and humid sub-tropical climate while high altitude regions are cold and temperature which can reach below zero during winter (PAN, 2009). Similarly, major monsoon in Nepal is dominated by south-easterly monsoon while winter monsoon by westerly (PAN, 2009; McSweeney \& Lizcano, 2008). Nepal is ranked fourth most vulnerable country to the impact of climate change (Maplecroft Climate Change Risk Atlas, 2011) and the seventh most affected country due to climate change in Climate Risk Index (Kreft, Eckstein, Dorsch \& Fisher, 2016). Similarly, MoSTE (2014) have identified Nepal as one of the four global hotspots for climate change risk due to its complex and extreme topography. This implies that though Nepal's contribution to greenhouse gases is negligible compared to developed countries, its risk to climate change is very high (Shrestha, Wake, Dibb \& Mayewski, 2000). The impact of climate change in Nepal is seen in various sectors like biodiversity, agriculture, livestock, water sources, soil, tourism, health, etc. (MoPE, 2017). The main impact of climate change is on water resources and deglaciation can change the hydrological characteristics of glacial fed rivers (MoPE, 2017).

Thus, it is important and necessary to understand the current scenario of climate trend of Nepal. In this regard, this article reviews different reports and research that have studied the climate change pattern and trend of Nepal along with people perception regarding climate change.

\section{Methodology}

Nepal lies in South Asia and is a land-locked country surrounded by India and China. Land area occupied by Nepal is 147,181 sq.km and average stretch from east to west is $885 \mathrm{~km}$ and width is $193 \mathrm{~km}$ from north to south. Nepal is situated between latitudes of $26^{\circ} 22^{\prime}$ to $30^{\circ} 27^{\prime \prime}$ north and longitudes of $80^{\circ} 04^{\prime}$ to $88^{\circ} 12^{\prime}$ East. The elevation ranges from $80 \mathrm{~m}$ above sea level to $8848 \mathrm{~m}$ (Mount Everest). Thus, the spatial variability of climate is also high which range from tropical to artic. Nepal can be divided onto five geographic region which are High Himalaya, Middle Mountain (Main Himalayas and Inner Himalayan Valleys), Mountains, Chure/Siwalik Hills and Tarai Plains. The maximum mean temperature can reach on an average $30^{\circ} \mathrm{C}$ in Tarai region to less than $0^{\circ} \mathrm{C}$ in High Himalaya (PAN, 2009). The temperature gradually decreases with increasing altitude. The precipitation pattern also varies in both north-south and east west directions. Summer monsoon contributes about $80 \%$ of total rainfall in Nepal (PAN, 2009). 


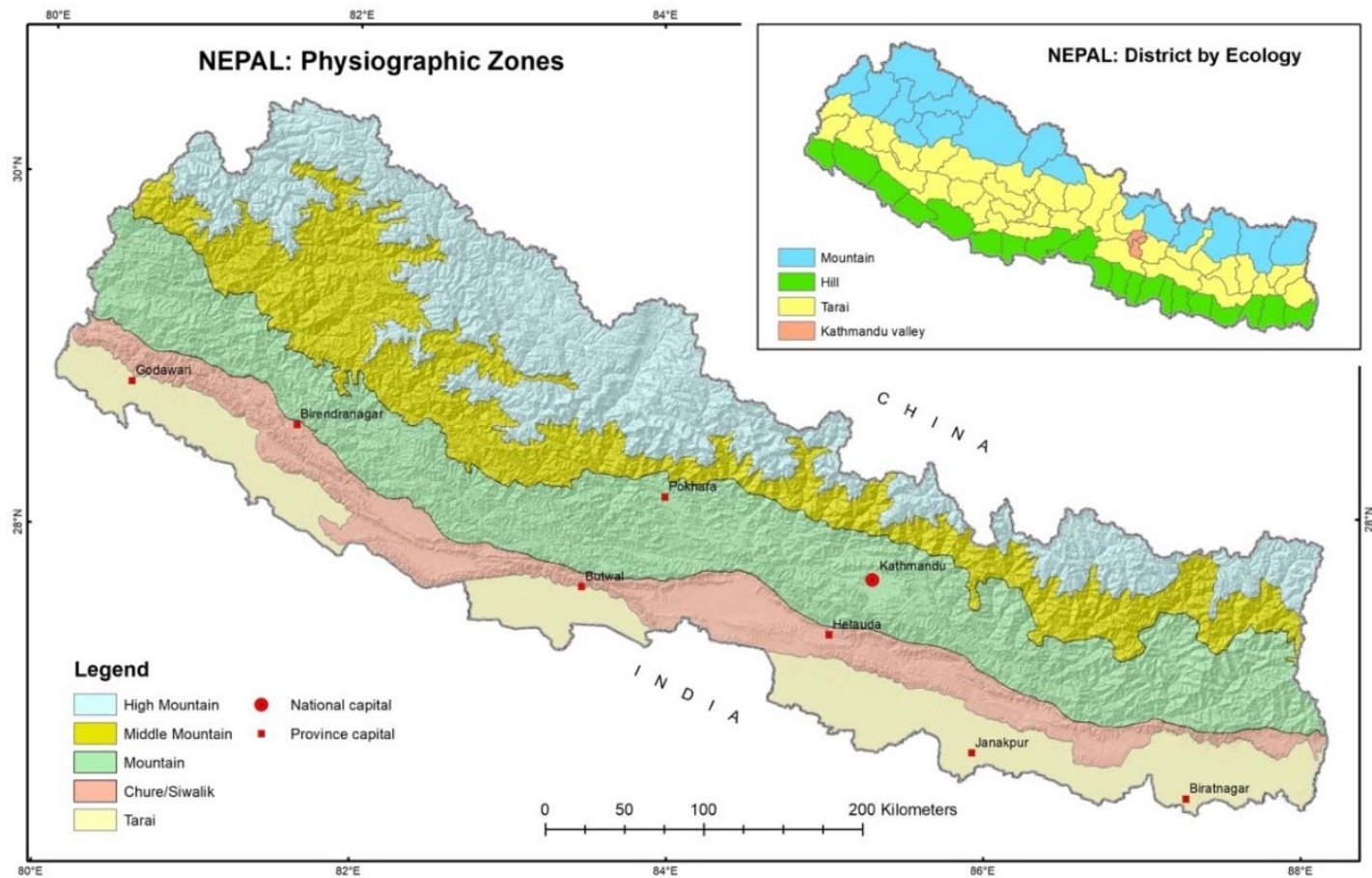

Figure 1: Physiographic zones of Nepal

Source: Department of Survey, Nepal

\section{Tools and technique}

The article reviews and compared the published articles which studies the pattern and trend of climate change of the time period at least 30 years. Researches that study the climate change of whole Nepal is only reviewed and those study which has only analyzed certain regions are not reviewed in this article.

\section{Result and discussion}

\section{Climate change situation of Nepal}

Department of hydrology and Meteorology, published a report on Observed Climate Trend Analysis of Nepal (1971-2014) on June 2017. In the study for temperature analysis daily temperature data was obtained from 93 stations. For trend and test of significance test non-parametric Mann-Kendall and Sen's Slope method was used. Maximum temperature was found to be in increasing trend all over Nepal in both annual and seasonal while minimum temperature was found to be increasing only during monsoon season. However, there was no significant trend observed for precipitation during any season. Both annual minimum and maximum temperature increased by $0.056^{\circ} \mathrm{C} /$ year and $0.002^{\circ} \mathrm{C} /$ year but this positive trend for 
minimum temperature was insignificant. Almost all district in all physiographic regions showed positive temperature trend in all seasons except few Tarai districts during winter. Manang had highest positive trend $\left(0.012^{\circ} \mathrm{C} /\right.$ year $)$ during winter season. The highest positive maximum temperature trend was observed in winter season in Tarai and in Siwalik and Middle mountain during monsoon.

The seasonal and annual temperature was related to altitude i.e. in lower altitude there was negative trend or small positive trend in relation to altitude while larger positive trend in higher regions. Most of the north-western districts had significant negative trend in winter and post-monsoon seasons while positive minimum temperature in most southern districts (Tarai to Middle Mountains) of Eastern Development Region Central Development Region and Western Development Region in all seasons. There was positive trend (insignificant) in lower elevation and negative in higher elevation for seasonal and annual minimum temperature. Dolpa observed highest positive trend $0.046^{\circ} \mathrm{C} /$ year in monsoon and Humla observed highest negative trend $-0.076^{\circ} \mathrm{C} /$ year in winter. Extreme precipitation trend showed significant positive and negative trend in northwestern or northern districts while extreme warm temperature was found to be increasing significantly in majority of districts. Similarly, the extreme cool temperature was observed to be increasing significantly, mainly in the northwestern parts of the country.

Department of Hydrology and Meteorology (DHM) published report on Study of Climate and Climatic variation over Nepal in 2015 it analyzed the general weather climate trend and it change over Nepal. Trend analysis for air temperature and precipitation was done for the period of 1971-2012. The report found out increasing trend for maximum temperature in large magnitude than minimum temperature for all seasons. The average trend for mean annual temperature is $0.04^{\circ} \mathrm{C} /$ year while for minimum temperature trend is only $0.01^{\circ} \mathrm{C} /$ year over Nepal. Tarai and Siwalik range have higher mean annual minimum temperature trend while lower for high altitude region. The pattern is reverse for mean annual maximum temperature i.e. higher in high altitude region and lower in low lying Tarai plains. For precipitation, there was positive trend in annual precipitation for eastern, central, western and far western development regions. In some small pocket areas increase by $30 \mathrm{~mm} /$ year and decrease by $40 \mathrm{~mm}$ /year was observed for annual precipitation. However, there was decreasing annual precipitation trend for most of the mid-western development region.

Practical Action Nepal Office (PAN) 2009, carried out the study of temperature and precipitation change of Nepal. They studied the change of temperature and precipitation from 1976-2005. The data for monthly precipitation were collected 
from 166 stations and monthly temperature records from 44 stations. The trend of variation rainfall and temperature (temporal and spatial) were analyzed using linear regression and time series analysis was used for future projection of climate trend of Nepal. The paper discusses the spatial and temporal rainfall and temperature pattern and compares it with the future trend of rainfall and temperature. The rainfall trend was found out be insignificant unlike temperature due to large inter annual rainfall variation.

According to the research, increase in annual rainfall trend in the eastern, central, western and far western regions while decreasing rainfall trend in most of the midwestern region was observed. However, Dolakha of Central Development Region saw the most decreasing annual trend by $40 \mathrm{~mm} /$ year. The pre-monsoon rainfall was on increasing trend in most of the eastern region by $9 \mathrm{~mm} /$ year while decreasing in Mid-Western and Far-Western Region by $4 \mathrm{~mm} /$ year. The maximum increasing pre-monsoon trend was observed in Myagdi, Kaski, Sindhupalchowk and Sankhuwasabha Districts and decreasing in areas like Dhankuta, Dolakha, Ramechhap and Tanahu. North-western parts of Nepal showed largest decreasing trend of pre-monsoon rainfall. Similarly, for monsoon season, increasing trend was observed in eastern, central, western and far western regions by $30 \mathrm{~mm} /$ year while mid-western region showed decreasing trend up to $30 \mathrm{~mm} /$ year. However, largest decreasing trend was observed in Dolakha and Solukhumbu of central and eastern regions. The trend for post monsoon rainfall was in increasing trend in most of the mid-western and the southern parts of eastern, central and western regions by almost $4 \mathrm{~mm}$ / year. Decreasing trend was observed in far western region and most of the northern parts of the country which was up to $7 \mathrm{~mm} /$ year. There is increasing winter rainfall trend on most of the parts of the country $(2.8 \mathrm{~mm} /$ year). However, decreasing winter rainfall trend was observed in few areas in northern parts of midwestern and eastern regions and also in some isolated pocket areas.

The temperature is in increasing trend of Nepal (PAN, 2009). The increase in maximum temperature was greater than increase in minimum temperature. Maximum temperature was found to be increasing by $0.05^{\circ} \mathrm{C} /$ year and minimum temperature by $0.03^{\circ} \mathrm{C} /$ year. Tarai had decreasing trend in maximum temperature during winter season thus indicating that the colder winter. Except few places (Sankhuwasabha, Sunsari, Nawalparasi, Banke and Bardia Districts) there was increasing trend in mean maximum annual temperature in all parts of the country. Similarly, southern parts or higher altitude had lower annual maximum temperature and higher in the northern parts of the country. The variation of minimum temperature was above $18^{\circ} \mathrm{C}$ in Tarai and it was below $6^{\circ} \mathrm{C}$ in north 
western parts of the country. Similar pattern was observed in both mean maximum and mean minimum temperature. Likewise, annual mean temperature was found to be decreasing trend in northern parts, in most of mid-western and far-western development regions while in southern parts of the country there was an increasing trend. Similarly, spatial variation of annual mean temperature was in increasing trend in almost all parts of the country except in Sankhuwasabha, Doti and northern parts of Nuwakot districts. The largest increasing annual mean temperature trend was found in Dhankuta and Lamjung Districts.

NCVST (2009), have projected that the mean annual temperature across Nepal can increase by 0.5 to $2.0^{\circ} \mathrm{C}$ by the 2030s which can reach to 1.7 to $4.1^{\circ} \mathrm{C}$, by the $2060 \mathrm{~s}$ and 3.0 to $6.3^{\circ} \mathrm{C}$ by the 2090s. The increase in temperature will be high in winter and pre-monsoon compared to monsoon and post-monsoon due to projected increase in monsoon rainfall and cloudiness. Increase in temperature is projected to be high in Western and Central Nepal by about $0.7^{\circ} \mathrm{C}$ than Eastern Nepal by 2090s. Similarly, hot days in pre-monsoon are to increase by $15-55 \%$ by 2060 s and $26-69$ by 2090 s while in monsoon it is projected to increase by $6-7 \%$ by 2060 s and $29-93$ by 2090 s. Similar clear trend was not found for precipitation. The projected mean annual precipitation showed both increase and decrease with -34 to $+22 \%$ by $2030,-36$ to + $67 \%$ by the 2060 s and -43 to $+80 \%$, by the 2090s. They have projected increase in monsoon rainfall of $+2 \%$ by 2030 s, $+7 \%$ by the 2060 s and $+16 \%$, by the 2090 s. Monsoon rainfall is expected to increase in Eastern and Central Nepal monsoon rainfall than Western Nepal. Winter precipitation is expected to decrease by $14 \%$. Also, heavy rainfall is projected to slightly rise in monsoon and post monsoon and slightly decrease in winter and pre-monsoon seasons.

McSweeney and Lizcano (2008) in their report UNDP Climate Change Country Profiles have studied the temperature and precipitation data from 1960 to 2003. They have concluded that mean annual temperature has not increased over Nepal in the period to 1960 to 2003 . However, the frequency of hot nights has increased while frequency of cold days and nights have decreased between these periods. The authors projected that the annual temperature to increase by $1.30 \mathrm{C}$ to $3.8^{\circ} \mathrm{C}$ by 2060s and 1.8 to $5.6^{\circ} \mathrm{C}$ by 2090s. Similarly, the precipitation trend in Nepal over the year 1960-2003 showed that there was decrease in annual precipitation by about 3.77 mm per month per decade. The authors projected mean annual precipitation to increase all over Nepal due to increase in wet season rainfall.

A study by Agarwala et al. (2003) by Organization of Economic Co- operation and Development (OECD) done by using GCM with the Special Report on Emissions Scenarios (SRES) B2 scenario projected increase in mean annual temperature by 
$1.2^{\circ} \mathrm{C}, 1.7^{\circ} \mathrm{C}$ and $3^{\circ} \mathrm{C}$ for 2030,2050 and 2100 respectively. Similarly, annual precipitation is projected to increase by $5,7.3$ and $12.6 \%$ for the same periods.

Shrestha, Wake, Paul and Jack (1999) collected temperature data from 49 stations and studied the temperature variation of the year 1971 to 1994 . He found out that temperature trend was either constant or decreasing before 1978 for all physiographical regions. But, after 1978 the temperature was in increasing trend. From the period of 1977 to 1994, the mean annual maximum temperature has been rising in most part of the country. The study shows average annual temperature increasing at the rate of $0.056^{\circ} \mathrm{C} /$ year. The maximum temperature was observed to be in increasing trend in most of the Himalayan region and middle mountains while cooling trend was observed in Tarai and the Siwalik region. Shrestha, Wake, Dibb and Mayewski (2000) studied change in precipitation of Nepal by collecting precipitation records form 78 stations distributed all across Nepal (1948-1994). The study concluded that the precipitation showed significant variability on annual and decadal time scales and predicts increasing precipitation trend by $5-15 \%$ due to increase in global temperature caused by global warming.

In 2016, CBS conducted National Climate Change Impact Survey (NCCIS) which provided data and knowledge on impact and effect of climate change on different sector. The report prepared by CBS, also provides the general knowledge and perception of local people on climate change and its impacts. According to the report majority of the local have seen the impacts of climate change on different sectors like biodiversity, tourism, human health, livestock etc. Nearly $50 \%$ of the household have heard about climate change and considered deforestation, natural disaster, and human intervention as major causes for climate change. Change in temperature and decrease in monsoon duration and winter rain were observed by most of the households. Almost $85 \%$ of the household experienced delay in monsoon and about $57 \%$ observed delay in winter rain.

\section{Conclusion}

Almost all of the studies reviewed in this article shows increase in maximum temperature compared to minimum temperature (DHM 2017; DHM 2015; PAN 2009; Shrestha, Wake, Paul \& Jack, 1999). Similarly, the increase in maximum temperature is more in higher altitude regions (DHM 2017; DHM 2015; PAN 2009; Shrestha, 1999). Likewise, minimum temperature is in decreasing trend in high altitude regions while increasing or positive trend observed in lower elevation regions (DHM 2017; DHM 2015; PAN, 2009). For maximum temperature, the trend was opposite i.e. increasing maximum temperature in higher altitude and 
decreasing maximum temperature in lower altitude (DHM 2017; DHM 2015; PAN, 2009; Shrestha, Wake, Paul \& Jack, 1999). This shows that higher altitudes are getting warmer. DHM (2017), shows all Nepal average temperature increasing by at $0.056^{\circ} \mathrm{C} /$ year while DHM (2015) shows increase by $0.04^{\circ} \mathrm{C} /$ year. Shrestha, Wake, Paul and Jack (1999) found out slightly high increasing trend of $0.059^{\circ} \mathrm{C}$. Similarly, DHM (2017) found minimum temperature trend increasing at $0.002^{\circ} \mathrm{C} /$ year while DHM (2015) and PAN (2009) showed $0.01^{\circ} \mathrm{C} /$ year and $0.03^{\circ} \mathrm{C} /$ year increase in minimum temperature respectively. Different studies have predicted different increase in temperature for future. NCVST (2009) predicted increase in temperature by 0.5 to $2.0^{\circ} \mathrm{C}$ by the $2030 \mathrm{~s}$ which can reach to 1.7 to $4.1^{\circ} \mathrm{C}$, by the $2060 \mathrm{~s}$ and 3.0 to $6.3{ }^{\circ} \mathrm{C}$ by the 2090s while Mc Sweeney et al. 2008projected that the annual temperature to increase by $1.3^{\circ} \mathrm{C}$ to $3.8^{\circ} \mathrm{C}$ by $2060 \mathrm{~s}$ and 1.8 to $5.6^{\circ} \mathrm{C}$ by $2090 \mathrm{~s}$ and Agarwala et al. (2003) projected increase in mean annual temperature by $1.2^{\circ} \mathrm{C}$, $1.7^{\circ} \mathrm{C}$ and $3^{\circ} \mathrm{C}$ for 2030,2050 and 2100 respectively.

In case of precipitation, there are different pattern observed by different studies which may be due to different methods used. However, most of the studies have concluded increase in precipitation in future (DHM 2017; DHM 2015; PAN 2009; NCVST 2009; McSweeney and Lizcano, 2008; Agarwala et al. 2003; Shrestha, Wake, Paul \& Jack, 1999).

According to the various studies reviewed, it is evident that the climate trends in Nepal are not uniform. There is deviation of climate trend from normal climate pattern in certain region. It is also evident that the temperature has been increasing and precipitation is also to increase in future. This abruption of normal climatic pattern can bring various kinds of calamities. Different studies have already found evidence of impacts of climate change like glacial melt, early blooming of plants, increase in drought and other disasters, etc. (MoPE, 2017; IPCC, 2012; IPCC, 2014; IPCC; 2018). Nepal is more vulnerable to the impacts of climate change. Thus, various programs should be conducted to increase awareness, develop adaptation and mitigate the impacts of climate change.

\section{Reference}

Agrawala, S.; Raksakulthai, V.; van Aalst, M.; Larsen, P.; Smith, J. \& Reynolds, J. 2003. Development and climate change in Nepal: Focus on water resources and hydropower. Environment directorate, Development Co-operation Directorate, Organization for Economic Co-operation and Development.

Central Bureau of Statistics (CBS). (2016). National climate change survey 2016. Kathmandu Central Bureau of Statistics, 
Devkota, P.R. (2014). Climate change: Trends and people's perception in Nepal. Journal of Environmental Protection. 28, 4431-4453.

Department of Hydrology and Meteorology (DHM). (2017). Observed climate trend analysis of Nepal (1971-2014). Kathmandu Department of Hydrology and Meteorology, Ministry of Population and Environment.

Department of Hydrology and Meteorology (DHM). (2015). Study of climate and climatic variation over Nepal. Department of Hydrology and Meteorology, Ministry of Population and Environment,

$\mathrm{Gu}, \mathrm{G}$ \& Adler, F.R. (2015). Spatial patterns of global precipitation change and variability during 1901-2010. Journal of Climate. 3(15), 1-15.

IPCC (2018). IPCC: retrieved October 25, 2018, from IPCC: http://www.ipcc.ch/report/sr15/

IPCC. (2014). Summary for policymakers. In: climate change 2014: Impacts, adaptation, and vulnerability. Part A: global and sectoral aspects. Contribution of working Group II to the fifth assessment report of the intergovernmental panel on climate change. Cambridge University Press, Cambridge, United Kingdom.

IPCC. (2012). Managing the risks of extreme events and disasters to advance climate change adaptation. A special report of working groups I and II of the intergovernmental panel on climate change. UK, and New York, Cambridge University Press, Cambridge.

Khadka, D \& Pathak, D. (2016). Climate change projection for the Marsyangdi River Basin, Nepal using statistical downscaling of GCM and its implications and geodisasters. Geoenvironmental Disasters. 3(15), 1-15.

Kreft, S.; Eckstein, D.; Dorsch, Fischer, L. 2016. Global climate risk index 2016. Ministry for Economic Cooperation and Development.

Maharjan, S., Sigdel, E., Sthapit, B. and Regmi, B. (2011) Tharu community's perception on climate changes and their adaptive initiations to withstand its impacts in Western Terai of Nepal. International NGO Journal, 6, 35-42.

Maplecroft. (2014). Verisk Maplecroft. Retrieved Septhember 20, 2018, from Maplecroft: https://www.maplecroft.com/about/news/ccoi.html

McSweeney, C.; New, M.; Lizcano, G. 2008. UNDP climate change country profiles: Nepal. Available at http://country-profiles.geog.ox.ac.uk (accessed on Sept 24, 2018). 
Ministry of Population and Environment (MoPE). (2017). Kathmandu, National adaptation plan formulation process. Government of Nepal,

MoSTE. (2014). Second national communication report to UNFCCC. http://unfccc. int/ resource/docs/natc/ nplnc2.pdf

NCVST. (2009). Vulnerability through the eyes of vulnerable: Climate change induced uncertainties and Nepal's development predicaments. Institute for Social and Environmental Transition-Nepal (ISET-N), Kathmandu.

Practical Action Nepal (PAN). (2009). Temporal and Spatial Variability of Climate Change over Nepal (1976-2005). Kathmandu. Practical Action Nepal,

Shrestha, A. B., C. P. Wake, J.E. Dibb, \& P. A. Mayewski (2000). Precipitation fluctuations in the Nepal Himalaya and its vicinity and relationship with some large-scale climatological parameters. International Journal of Climatology 20(3). 317-327.

Shrestha, A. B., C. P. Wake, Paul, A.M \& Jack, E.D. (1999). Maximum temperature trends in the Himalaya and its vicinity: An analysis based on temperature records from Nepal for the period 1971-94. Journal of Climate 12. 2775-2787. 